\title{
PENERAPAN INKUIRI TERBIMBING MELALUI IMPLEMENTASI LESSON STUDY UNTUK MENINGKATKAN HASIL BELAJAR KOGNITIF SISWA KELAS XI IPA-2 MAN GONDANGLEGI KABUPATEN MALANG
}

\author{
Dyah Ayu Fajarianingtyas \\ Program StudiPendidikan BiologiProgram Pascasarjana \\ Universitas Negeri Malang
}

\begin{abstract}
ABSTRAK
Tujuan penelitian ini adalah untuk mengetahui penerapan inkuiri terbimbing melalui implementasi Lesson Study dapat meningkatkan hasil belajar kognitif siswa kelas XI IPA-2 MAN Gondanglegi Malang.Pendekatan yang digunakan adalah pendekatan kualitatif dengan jenis penelitian tindakan kelas (Classroom Action Research) atau PTK.Subjek penelitian ini adalah siswa kelas XI IPA-2 Tahun Pelajaran 2011/2012 yang berjumlah 36 siswa.Materi pembelajaran yang digunakan untuk penelitian ini adalah Sistem Gerak.

Dari tindakan yang dilaksanakan peneliti dan pengamat dapat dilaporkan adanya peningkatan hasil belajar kognitif siswa dengan menggunakan inkuiri terbimbing.Penerapan inkuiri terbimbing melalui implementasi Lesson Study pada kelas XI IPA-2, siswa terlibat langsung dalam mempelajari dan memahami materi, siswa secara aktif bersama-sama siswa yang lain membahas dan memahami materi dalam kelompok. Pada pokok bahasan Sistem Gerak, tahap pertama siswa dibentuk dalam kelompok-kelompok dimana setiap kelompok membahas dan mempelajari serta memahami secara bersama-sama materi dan lembar kerja siswa yang telah ditentukan dan tahap kedua guru menyampaikan penguatan konsep pada materi tersebut.

Hasil analisis data menunjukkan nilai rata-rata kelas dari siklus 1 dan siklus 2 pembelajaran Biologi siswa kelas XI IPA-2 dengan model pembelajaran inkuiri terbimbing mengalami peningkatan, yaitu sebesar $19,15 \%$. Hal ini menunjukan bahwa terdapat peningkatan hasil belajar kognitif siswa pada mata pelajaran Biologi.
\end{abstract}

Kata Kunci: Inkuiri Terbimbing, lesson study, kognitif

\section{PENDAHULUAN}

Pendidikan memberikan kontribusi terhadap kemajuan suatu bangsa. Sekolah sebagai suatu institusi atau lembaga pendidikan seharusnya mampu berperan dalam proses edukasi (proses pendidikan yang menekankan pada kegiatan mendidik dan mengajar), proses sosialisasi (proses bermasyarakat khususnya bagi anak didik), dan proses transformasi (proses perubahan tingkah laku ke arah yang lebih baik).

Salah satu upaya peningkatan mutu pendidikan adalah penyempurnaan kurikulum.Kurikulum yang disempurnakan saat ini berkembang dengan pendekatan Kurikulum Tingkat Satuan Pendidikan (KTSP). KTSP merupakan paradigma baru pengembangan kurikulum yang memberikan otonomi luas pada setiap satuan pendidikan, dan pelibatan masyarakat dalam rangka mengefektifkan proses belajar-mengajar di sekolah.
Otonomi diberikan agar setiap satuan pendidikan dan sekolah memiliki keleluasaan dalam mengelola sumber daya, sumber dana, sumber belajar, dan mengalokasikannya sesuai prioritas kebutuhan, serta lebih tanggap terhadap kebutuhan setempat (Mulyasa, 2007:19).

Berdasarkan Permen Diknas No.22 tahun 2006, tentang standar isi, dijelaskan bahwa Ilmu Pengetahuan Alam (IPA) berkaitan dengan cara mencari tahu (inquiry) tentang alam secara sistematis, sehingga IPA bukan hanya sebagai penguasaan kumpulan pengetahuan yang berupa fakta-fakta, konsep-konsep atau prinsip-prinsip saja, tetapi juga merupakan suatu proses penemuan. Pendidikan IPA di sekolah menengah diharapkan dapat menjadi wahana bagi peserta didik untuk mempelajari diri sendiri dan alam sekitar, serta prospek pengembangan lebih lanjut dalam menerapkannya di dalam kehidupan sehari-hari. Pendidikan IPA menekankan 
pada pemberian pengalaman langsung untuk mengembangkan kompetensi agar peserta didik menjelajahi dan memahami alam sekitar secara ilmiah. Pendidikan IPA diarahkan untuk mencari tahu dan berbuat sehingga dapat membantu peserta didik memperoleh pemahaman lebih mendalam tentang dirinya sendiri dan alam sekitar.

$$
\text { Guru seyogyanya mulai }
$$

meninggalkan cara-cara rutinitas dalam pembelajaran, tetapi lebih menciptakan program-program pengembangan yang profesional. Upaya tersebut merupakan implikasi dari reformasi pendidikan dengan tujuan agar mampu mencapai peningkatan perolehan belajar siswa secara memadai.Program-program pengembangan profesi guru tersebut membutuhkan fasilitas yang dapat memberi peluang kepada mereka learning how to learn dan to learn about teaching. Salah satu upaya tersebut dapat dilakukan melalui implementasi lesson study.

Lesson Study $(L S)$ merupakan suatu pendekatan peningkatan pembelajaran yang awal mulanya berasal dari Jepang. Di Indonesia, LS telah diterapkan di tiga daerah (Malang, Yogyakarta, dan Bandung) sejak tahun 2006 melalui skema Strengthening In-Service Teacher Training of Mathematics and Science (SISTTEMS)(Susilo, 2008). Lesson Study merupakan suatu model pembinaan profesi pendidik melalui pengkajian pembelajaran secara kolaboratif dan berkelanjutan berlandaskan prinsipprinsip kolegalitas dan mutual learning untuk membangun learning community. Lesson Study bukan suatu metode pembelajaran atau suatu strategi pembelajaran, tetapi dalam kegiatan Lesson Study dapat memilih dan menerapkan berbagai metode/strategi pembelajaran yang sesuai dengan situasi, kondisi, dan permasalahan yang dihadapi pendidik. Lesson study dapat merupakan suatu kegiatan pembelajaran dari sejumlah guru dan pakar pembelajaran yang mencakup 3 (tiga) tahap kegiatan, yaitu perencanaan (planning), implementasi (action) pembelajaran dan observasi serta refleksi (reflection) terhadap perencanaan dan implementasi pembelajaran tersebut, dalam rangka meningkatkan kualitas pembelajaran.

MAN Gondanglegi merupakan salah satu sekolah swasta setingkat SMA di Kabupaten Malang dengan struktur budaya lokal yang bercorak kehidupan pesantren di bawah naungan Kemennag RI, diketahui bahwa umumnya input siswa MAN Gondanglegi adalah lulusan Madrasah tsanawiyah dan SMP Negeri ataupun swasta yang kurang bagus, sehingga untuk menghasilkan lulusan atau output yang mampu bersaing di jenjang universitas, perlu proses pembelajaran yang lebih bermakna bagi siswa. Dalam bidang pendidikan, Gondanglegi merupakan miniatur dari kondisi pendidikan Indonesia yang perlu diperhatikan. Pada proses pembelajaran siswa tidak termotivasi dengan baik, pelajaran biologi bagi siswa dianggap pelajaran hafalan sehingga siswa kurang termotivasi dalam belajarnya. Salah satu alasan siswa berpendapat demikian karena di dalam mata pelajaran Biologi banyak istilah-istilah bahasa latin atau yang dilatinkan yang dirasa sulit oleh siswa. Berdasarkan kenyataan di lapangan hasil belajar mata pelajaran biologi di MAN Gondanglegi masih rendah belum memenuhi kriteria ketuntasan minimal (KKM) yaitu 75. (Sumber: Buku Daftar Nilai Guru).

$$
\text { Pembelajaran IPA di MAN }
$$

Gondanglegi belum pernah diarahkan pada pembelajaran inkuiri seperti yang telah diamanatkan dalam kurikulum. Proses pembelajaran lebih banyak ke guru sebagai pusat pembelajaran (teacher centered) yang diselingi dengan penugasan serta diskusi. Model pembelajaran inkuiri terbimbing melalui Lesson study maka guru diharapkan mampu menciptakan kelas sebagai laboratorium demokrasi, supaya pelajar terlatih dan terbiasa berbeda pendapat. 
Kebiasaan ini penting dikondisikan sejak di bangku sekolah, agar pelajar memiliki sikap jujur, sportif dalam mengakui kekurangannya sendiri dan siap menerima pendapat orang lain yang lebih baik, serta mampu mencari penyelesaian masalah.

Pembelajaran Biologi di kelas XI

IPA MAN Gondanglegi dari segi proses dan output masih belum memuaskan. Dari segi proses pembelajaran biologi belum semuanya berinkuiri untuk memahami konsep sehingga hasil belajar kognitif maupun hasil belajar psikomotorik belum memuaskan. Hal ini berdasarkan hasil survei pada tanggal 30 September 2011 bahwa nilai Biologi semester lalu pada siswa kelas XI IPA-2 yang kurang memuaskan, adanya minim fasilitas di Laboratorium MAN Gondanglegi sehingga siswa XI IPA-2 jarang melakukan praktikum, dan pembelajaran inkuiri jarang dilaksanakan di MAN Gondanglegi sehingga jarang dituangkan dalam rencana pembelajaran secara detail. Begitu pula dengan penerapan strategi inkuiri guru-guru IPA di MAN Gondanglegi belum pernah sama sekali menerapkanannya dalam pembelajaran.

Faktor lain juga bisa dipengaruhi bahwa tidak semua guru Biologi di MAN Gondanglegi memiliki kemampuan dalam menciptakan pembelajaran yang tepat dan bermutu. Seorang guru memerlukan pengalaman dan terus latihan untuk melakukan inovatif pembelajaran. Berdasarkan hasil survey, sebagian besar guru MAN Gondanglegi belum mengetahui Lesson Study dan sebagian dari mereka ingin ber-Lesson Study dalam pembelajarannya. Baru sebagian kecil dari mereka yang sudah memahami Lesson Study tetapi belum pernah sama sekali dilaksanakan dalam pembelajaran. Oleh karena itu, PTK dalam kerangka Lesson Study perlu dilaksanakan di MAN Gondanglegi demi meningkatkan kinerja guru dalam mengajar serta meningkatkan hasil belajar siswa. Dalam pelaksanaan proses pembelajaran, guru-guru di MAN Gondanglegi tidak terbiasa merancang atau membuat RPP sendiri, biasanya RPP diperoleh dari teman atau download dari internet. RPP dibuat hanya pada saat diminta oleh Kepala Madrasah atau jika akan ada pemeriksaan dari pengawas maupun dari tim akreditasi. Guru-guru belum terbiasa melaksanakan pembelajaran sesuai RPP dan belum pernah merefleksi proses pembelajaran yang telah dilaksanakan.

Guru-guru MAN Gondanglegi tidak terbiasa membuat LKS sendiri, LKS biasanya di drop oleh sekolah dari penerbit tertentu yang telah dipilih oleh guru bidang studi, tanpa memperhatikan apakah LKS itu sesuai dengan kebutuhan siswa atau tidak, bahkan tidak disesuikan dengan kurikulum. Oleh karena itu guruguru di MAN Gondanglegi harus ditingkatkan kinerjanya dalam merencanakan, melaksanakan, maupun merefleksi proses pembelajaran, selain itu guru juga harus ditingkatkan kinerjanya dalam merancang dan melaksanakan pembelajaran.

Salah satu model pembelajaran yang menekankan pada pengalaman lapangan seperti mengamati gejala atau mencoba suatu proses kemudian mengambil kesimpulan adalah inkuiri. Kelebihan dari metode inkuiri adalah siswa memiliki pemahaman terhadap suatu konsep dan siswa mampu berpikir kreatif. Strategi yang sesuai dengan kondisi di atas menurut peneliti adalah inkuiri terbimbing. Inkuiri adalah suatu proses untuk memperoleh dan mendapatkan informasi dengan melakukan observasi dan atau eksperimen untuk mencari jawaban atau memecahkan masalah terhadap pertanyaan atau rumusan masalah dengan menggunakan kemampuan berpikir kritis dan logis (Schmidt, 2003). Inkuiri sebenarnya merupakan prosedur yang biasa dilakukan oleh ilmuwan dan orang dewasa yang memiliki motivasi tinggi dalam upaya memahami fenomena alam, memperjelas pemahaman, dan menerapkannnya dalam kehidupan sehari-hari (Hebrank, 2000; 
Budnitz, 2003; Chiapetta \& Adams, 2004). Umumnya pada proses belajar mengajar pada inkuiri terbimbing masalah dari guru diberikan dalam bentuk pertanyaan open-ended yang mengarah pada pengembangan tambahan kegiatan penyelidikan yang dapat dilakukan oleh siswa.

Pada penerapan proses belajar mengajar dengan menggunakan metode Inkuiri terbimbing, siswa dituntut untuk menemukan konsep melalui petunjuk seperlunya dari seorang guru. Petunjukpetunjuk tersebut pada umumnya berupa pertanyaan-pertanyaan yang bersifat membimbing. Guru juga memberikan pengarahan-pengarahan.

Berdasarkan latar belakang di atas, peneliti melakukan penelitian tindakan kelas dengan judul Penerapan Inkuiri Terbimbing Melalui Implementasi Lesson Study untuk Meningkatkan Hasil Belajar Kognitif dan Hasil Belajar Psikomotor
Siswa Kelas XI IPA-2 MAN Gondanglegi Kabupaten Malang.

\section{METODE PENELITIAN}

Pendekatan yang digunakan dalam penelitian ini adalah pendekatan kualitatif. Penelitian ini termasuk jenis penelitian tindakan kelas (Classroom Action Research) atau PTK. Subjek penelitian ini adalah siswa kelas XI IPA-2 Tahun Pelajaran 2011/2012 yang berjumlah 36 siswa.

Pelaksanaan penelitian tindakan kelas ini direncanakan terdiri dari dua siklus. Setiap siklusnya terdiri dari empat tahap, yang meliputi.

1. Perencanaan tindakan (planning)

2. Pelaksanaan tindakan (action)

3. Pengamatan (observation)

4. Refleksi (reflection)

Tahapan dalam siklus penelitian tindakan kelas dapat dilihat pada Gambar 1.
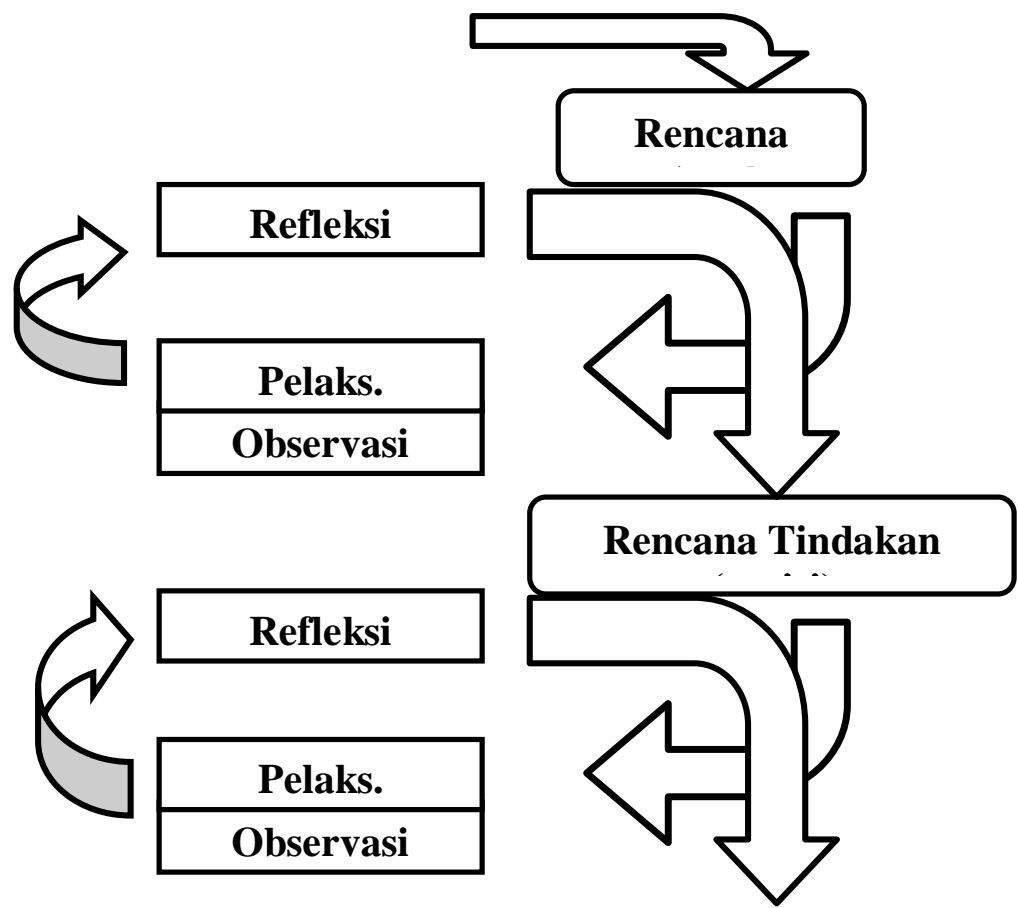

Gambar 1. Siklus Penelitian Tindakan Kelas yang Dikembangkan oleh Kemmis \& Mc Taggart (Sumber: Depdiknas, 2005: 6)

\section{HASIL DAN PEMBAHASAN}

\section{A. Data Hasil Belajar Kognitif Siswa}

Data hasil kognitif siswa yang dikumpulkan penulis dalam penelitian dengan pemberian soal melalui lembar kerja siswa untuk siklus I dan siklus II, dapat dilihat pada Tabel 1: 
Tabel 1 Data Nilai Rata-Rata Kelas Tes Formatif Pada Setiap Siklus

\begin{tabular}{|l|l|c|c|c|}
\hline \multirow{2}{*}{ No } & \multirow{2}{*}{ Subjek } & \multicolumn{2}{|c|}{$\begin{array}{c}\text { Nilai rata-rata } \\
\text { pada siklus }\end{array}$} & $\begin{array}{c}\text { Persentase } \\
\text { Peningkatan } \\
\end{array}$ \\
\cline { 3 - 4 } & & I & II & $(\%)$ \\
\hline 1. & Pretest & 47,76 & 65,24 & $36,58 \%$ \\
\hline 2. & Postest & 74,79 & 89,12 & $19,15 \%$ \\
\hline
\end{tabular}

\section{B. Data HasilPengamatan (Observasi)}

Hasil observasi terdiri dari dua pengamatan (penilaian lembar observasi), pertama performa siswa dan kelompok yang dilakukan oleh peneliti dalam bentuk tes formatif dan Lembar Kerja Siswa untuk mengetahui kemampuan siswa selama pembelajaran, dan kedua yaitu keterlaksanaan pembelajaran. Hasil pengamatan observer terhadap kelas pada siklus satu, yaitu kemampuan siswa adalah kurang baik dan kurang aktif dalam mengikuti pembelajaran dan diskusi, hal ini terlihat dari nilai rata-rata data pengamatan dengan aspek yang dinilai yaitu merumuskan masalah, membuat hipotesa, merencanakan kegiatan, melaksanakan kegiatan, mengumpulkan data dan mengambil kesimpulan. Hal ini dipengaruhi kurang terbiasanya menjalani rutinitas belajar yang student centered, siswa hanya terpaku pada LKS dari guru yang langsung mendapat jawaban tanpa melalui proses praktikum dalam menemukan sendiri konsepnya dari sumber lain. Hal ini terlihatdari nilai rata-rata data pengamatan pada inkuiri terbimbing.

Hasil observasi keterlaksanaan pembelajaran menunjukkan bahwa pembelajaran dengan model inkuiri terbimbing, baik dari kegiatan guru maupun siswa terlaksana dengan baik sesuai dengan apa yang direncanakan.

Dari tindakan yang dilaksanakan peneliti dan pengamat dapat dilaporkan adanya peningkatan hasil belajar kognitif siswa dengan menggunakan inkuiri terbimbing. Penerapan inkuiri terbimbing melalui implementasi Lesson Study pada kelas XI IPA-2, siswa terlibat langsung dalam mempelajari dan memahami materi, siswa secara aktif bersama-sama siswa yang lain membahas dan memahami materi dalam kelompok. Pada pokok bahasan Sistem Gerak, tahap pertama siswa dibentuk dalam kelompokkelompok dimana setiap kelompok membahas dan mempelajari serta memahami secara bersama-sama materi dan lembarkerja siswa yang telah ditentukan dan tahap kedua guru menyampaikan penguatan konsep pada materi tersebut.

Pada penerapan inkuiri terbimbing materi Sistem Gerak ini dibagi menjadi dua siklus dengan tiga kali pertemuan setiap siklusnya.Materi diskusi pertemuan pertama penerapan inkuiri terbimbing yaitu tentang Tulang dan kelainannnya sedangkan materi pada pertemuan kedua tentang Otot dan kelainannya. Pada tahap pertama yaitu menghadapkan pada masalah maka kegiatan siswa memecahkan masalah yang diberikan oleh guru.Tahap kedua mengumpulkan data terhadap masalah maka kegiatan siswa mendefinisikan dan mengorganisasikan tugas belajar yang berhubungan dengan masalah. Tahap ketiga membimbing penyelidikan individual maupun kelompok maka kegiatan siswa mengumpilkan informasi yang sesuai untuk melaksanakan eksperimen agar mendapatkan penjelasan dan pemecahan masalah. Tahap keempat yaitu mengorganisir data dan merumuskan penjelasan maka kegiatan siswa mengorganisir dan merumuskan penjelasan terhadap masalah.Tahap kelima yaitu menganalisis dan mengevaluasi proses pemecahan masalah maka kegiatan siswa mengalisis hasil temuan mereka, serta mengajukan pertanyaaan yang lebih efektif dan produktif. Untuk pertemuan akhir, setiap siklusny adilakukan tes kemampuan akhir untuk mengetahui hasil belajar siswa pada tes Formatif.

Penerapan inkuiri terbimbing dilakukan dalam tiga pertemuan pada siklus pertama, pada pertemuan pertama 
suasana kelas terlihat kurang kondusif, siswa masih tampak kurang termotivasi dan tertarik untuk aktif dalam praktikum, kerjasama siswa kurang terbentuk baik dalam diskusi kelompok maupun dalam persentasi kelas, namun dari segi alokasi waktu penerapan model pembelajaran ini sudah cukup sesuai dengan rencana pembelajaran. Pada pertemuan kedua penerapan inkuiri terbimbing siswa belum tampak terbiasa dengan penerapan model ini, pada saat praktikum maupun diskusi kelas terlihat siswa belum dapat bekerjasama dengan cukup baik dan bertanggungjawab, sebagian siswa masih pasif dalam mengajukan pertanyaan maupun melakukan praktikum, tetapi alokasi waktu telah sesuai dengan rencana pembelajaran. Hal ini disebabkan karena siswa masih belum terbiasa dengan teknik pembelajaran ini, pembagian kelompok kerja siswa yang terlampau besar sehingga kerja sama kurang tercipta, adanya praktikum maupun diskusi pada setiap tatap muka, dan materi Sistem Gerak yang diberikan sangat padat dalam satu kali tatap muka sehingga kurang dipahami oleh para siswa. Observasi ini dilakukan ketika pelaksanaan pembelajaran pada tahap refleksi dan pengerjaan lembar kerjasiswa untuk kelompok. Dengan hasil refleksi yang kurang memuaskan, peneliti memutuskan untuk melakukan siklus II.

Kelemahan ini dijadikan bahan pertimbangan untuk pelaksaan siklus II.Hal-hal yang dilakukan di antaranya (1) mengubah Rencana Pokok Pembelajaran, (2) mengubah susunan denah tempat duduk untuk mengubah suasana, dan (3) mengubah pembagian kelompok menjadi lebih banyak lagi.

Untuk penerapan inkuiri terbimbing siklus II, pertemuan pertama suasana kelas terlihat sudah kondusif, siswa tidak malu untuk aktif dalam diskusi, dan kerjasama siswa sudah terbentuk baik dalam diskusi kelompok maupun dalam persentasi kelas, dari segi alokasi waktu penerapan model pembelajaran ini sudah sesuai dengan rencana pembelajaran.

Hasil analisis data menunjukkan nilai rata-rata kelas dari siklus 1 dan siklus 2 pembelajaran Biologi siswa kelasXI IPA-2 dengan model pembelajaran inkuiri terbimbing mengalami peningkatan, yaitusebesar19,15\%. Hal ini menunjukan bahwater dapat peningkatan hasil belajar kognitif siswa pada mata pelajaran Biologi. Faktor di atasdisebabkanbahwapada model pembelajaran inkuiriter bombing siswa dapat memahami suatu konsep, karena siswa mengalami sendiri proses untuk mendapatkan konsep, siswa didorong untuk berpikir dan bekerja atas inisiatif sendiri, sehingga lebih merangsang kemauan diri siswa, melatih siswa memecahkan masalah secara mandiri namun terbimbing, siswa memiliki keterampilan berpikir kritis karena mereka dituntut untuk selalu menganalisis dan menangani informasi yang diperoleh, siswa dapat membentuk dan mengembangkan konsep diri.

Pada dasarnya Inkuiri Terbimbing lebih cocok diberikan pada siswa yang belum berpengalaman belajar dengan mengunakan metode inkuiri. Pada tahap permulaan siswa lebih banyak diberikan bimbingan, namun sedikit demi sedikit bimbingan tersebut akan dikurangi. Pada saat menemukan suatu konsep, siswa masih memerlukan bimbingan bahkan guru perlu memberikan bantuan setapak demi setapak. Siswa memerlukan bantuan dalam mengembangkan kemampuannya untuk memahami pengetahuan baru. Walaupun siswa harus berusaha mengatasi kesulitan yang dihadapi tetapi bantuan guru masih diperlukan. Pada pembelajaran ini siswa mulai terlibat aktif dalam pembelajaran. Hal ini dapat dilihat pada hasil lembar observasi menunjukkan bahwa mereka menyukai model pembelajaran ini namun belum terbiasa karena model pembelajaran ini masih baru 
bagi siswa kelas XI IPA-2 di MAN Gondanglegi Malang.

Dalam model pembelajaran tersebut, siswa yang biasanya belajar secara individu, tanpa kompetisi dan tanpa praktikum maupun aktivitas sederhana dalam setiap pembelajaran dicoba dikondisikan dengan adanya kompetisi dan praktikum maupun aktivitas sederhana sehingga termotivasi bagi keberhasilan belajar mereka, serta suasana pembelajaran dapat menjadi lebih hidup dan bervariasi. Model pembelajaran ini juga dapat menciptakan suasana kegiatan belajar mengajar yang baik karena siswa tidak cepat merasa bosan dalam belajar dan dapat meningkatkan rasa percaya diri karena siswa dilatih untuk aktif berpendapat, menghargai perbedaan pendapat dan termotivasi untuk meningkatkan prestasinya. Model pembelajaran Inkuiri Terbimbing sesuai dengan tuntutan pendidikan IPA yang diarahkan untuk mencari tahu dan berbuat sehingga dapat membantu peserta didik untuk memperoleh pemahaman mendalam tentang dirinya sendiri dan alam sekitar.

Hasil penelitian ini sejalan pula dengan hasil penelitian yang dilakukan oleh Khusnur Rozi yang melaksanakan pembelajaran inkuiri di SMA Negeri I Pandaan (2010), hasil penelitian menunjukkan bahwa pemahaman konsep siswa yang belajar dengan strategi pembelajaran inkuiri terbimbing lebih tinggi dari pada yang menggunakan inkuiri terstruktur.

\section{KESIMPULAN}

1. Untuk melaksanakan peningkatan hasil belajar kognitif siswa dapat dilakukan dengan menggunakan model pembelajaran Inkuiri terbimbing melalui implementasi Lesson Study.

2. Terdapat peningkatan yang signifikan terhadap hasil belajar kognitif pada siswa kelas XI IPA-2 MAN Gondanglegi Malang.

\section{DAFTAR PUSTAKA}

Rivers, W. Summer . 2001. Autonomy at All Cosis. An Ethnography of Metacognitive Self-Assessment and Self-Management among Experienced Language Leaners. Moderns Language Journal 86, no 2: 279-290.

Slavin, E. R. 2000, Educational Psychology, Theory and Practice. 6th Ed. Boston, London, Toronto, Sydney, Tokyo, Singapore: Allyn and Bacon.

Susilo, H., Chotimah, H. \& Sari D. Y. 2008. Penelitian Tindakan Kelas. Malang : Banyumedia Publishing.

Arends, R.I. 2008. Learning to Teach (Belajar untuk Mengajar). (7). 1. Penerjemah Helly Prajitno Soetjipto. Yogyakarta: Pustaka Belajar.

Arikunto, Suhardjono, \& Supardi. 2007. Penelitian Tindakan Kelas. Jakarta: PT. Bumi Aksara.

Arikunto, S. dan Jabar A.S.C. 2009.Evaluasi Program Pendidikan Pedoman Teoritis Praktis bagi Mahasiswa dan Praktisi Pendidikan. (2) Jakarta: Bumi Aksara.

Depdiknas. 2005. Ilmu Pengetahuan Alam. Materi Pelatihan Terintegrasi. Jakarta: Direktorat Jenderal Pendidikan Dasar dan Menengah.

Dimyati dan Mudjiono. 2006. Belajar dan Pembelajaran. Jakarta: Rineka Cipta.

Eggen, P. D., \& Kauchak D. P. 1996. Strategies for Teachers: Teaching Content and Thinking Skills. Third Edition. Allyn \& Bacon

Ibrohim. 2009. Pengaruh Model Implementasi Lesson Study Kegiatan MGMP Terhadap Peningkatan Kompetensi Guru dan Hasil Belajar Biologi Siswa. Disertasi tidak diterbitkan. Program Pascasarjana UM Malang.

Lewis, Catherine C.2002. Lesson Study: A Handbook of Teacher Led 
Instructioal Change. Philadelphia, PA: Research for Better School, Inc. Lewis, Catherine: Perry, Rebecca; and Murata, Aki. 2006. How Should Research Contribute to Instructional Improvement? The Case of Lesson Study.Educational Researcher 35(3):3-14.

Mbulu, Joseph. 2001. Pengajaran Individual: Pendekatan, Metode, Dan Media, Pedoman Mengajar Bagi Guru Dan Calon Guru. Malang: Elang Mas.

Mulyasa, E. 2007. Kurikulum Tingkat Satuan Pendidikan. Bandung: PT. Remaja Rosda Karya. hlmn 19

Nurhadi, Yasin.2004. Pembelajaran Kontekstual dan Penerapannya dalam KBK, UM Press. Malang

Nurhadi, Yasin, \& Senduk. 2004. Pembelajaran Kontekstual (Contextual Teaching and Learning/(CTL) dan Penerapannya dalam KBK. Malang: Penerbit Universitas Negeri Malang (UM Press). 